\title{
The carbon budget of the Baltic Sea
}

\author{
K. Kuliński and J. Pempkowiak \\ Institute of Oceanology, Polish Academy of Sciences, ul. Powstańców Warszawy 55, 81-712 Sopot, Poland
}

Received: 26 April 2011 - Published in Biogeosciences Discuss.: 16 May 2011

Revised: 24 October 2011 - Accepted: 24 October 2011 - Published: 9 November 2011

\begin{abstract}
This paper presents the results of a comprehensive study of the Baltic Sea carbon budget. The Baltic Sea is very much influenced by terrestrial carbon input. Rivers are the largest carbon source, and their input amounts to $10.90 \mathrm{Tg} \mathrm{C} \mathrm{yr}^{-1}\left(\mathrm{Tg}=10^{12} \mathrm{~g}\right)$ with a $37.5 \%$ contribution of organic carbon. On the other hand, carbon is effectively exported from the Baltic to the North Sea $\left(7.67 \mathrm{Tg} \mathrm{C} \mathrm{yr}^{-1}\right.$ ) and is also buried in bottom sediments $\left(2.73 \mathrm{Tg} \mathrm{C} \mathrm{yr}^{-1}\right)$. The other sources and sinks of carbon are of minor importance. The net $\mathrm{CO}_{2}$ emission $\left(1.05 \mathrm{Tg} \mathrm{Cyr}^{-1}\right)$ from the Baltic to the atmosphere was calculated as the closing term of the carbon budget presented here. There is a net loss of organic carbon, which indicates that the Baltic Sea is heterotrophic.
\end{abstract}

\section{Introduction}

Shelf seas play a key role in the global fluxes of matter and energy between the land, ocean and atmosphere (Thomas et al., 2009). Although they make up a little over $7 \%$ of the global sea surface and less than $0.5 \%$ of the ocean volume, shelf seas are responsible for $15-30 \%$ of marine primary production and as much as $80 \%$ of organic matter burial (Walsh, 1991; Borges, 2005; Bozec et al., 2005; Chen and Borges, 2009). These features of shelf seas are due to the high biological activity they support, which is driven by nutrient inputs from all of the adjacent environments (Gattuso et al., 1998; Pätsch and Kühn, 2008; Thomas, 2009).

As a consequence of this high biological productivity, most global shelf seas are believed to act as net sinks for anthropogenic $\mathrm{CO}_{2}$ (e.g. Chen et al., 2003; Borges et al., 2005; Chen and Borges, 2009; Laruelle et al., 2010). Moreover, the $\mathrm{CO}_{2}$ loads absorbed by shelf seas exceed those reported from

Correspondence to: K. Kuliński

(kroll@iopan.gda.pl) the open ocean (Chen and Borges, 2009; Takahashi et al., 2009). It has recently been suggested that in contrast to open shelf seas, some near-shore zones are identified as sources of $\mathrm{CO}_{2}$ to the atmosphere (Chen and Borges, 2009; Liu et al., 2010b; Laruelle et al., 2010). Consequently, detailed studies of the carbon cycle in shelf seas are still required in order to clarify its role in the global carbon cycle. Although several attempts have been made to quantify the role of shelf seas in global $\mathrm{CO}_{2}$ fluxes (Tsunogai et al., 1999; Andersson and Mackenzie, 2004; Thomas et al., 2004), validation of the outcome of these studies must be based on compilations of the results of local studies. These enable the multifarious locally specific processes, which influence $\mathrm{CO}_{2}$ exchange between seawater and the atmosphere and these processes must be taken into consideration (Borges, 2005; Borges et al., 2005; Chen and Borges, 2009).

The Baltic Sea is a spatially and temporally highly diverse ecosystem (Dippner et al., 2008; HELCOM, 2009). The ecosystem diversity is extended in the direction from South-West, influenced by the high saline North Sea water inflows, to North-East - being under high influence of the freshwater inflow. This salinity gradient induces the biodiversity gradient with a minimum in the Gulf of Bothnia (Fig. 1). Such a diversity pattern is strengthened with the temperature and irradiation gradients that influence duration of the vegetation period. Biological activity is much higher in the southern, warmer, part of the Baltic Sea. Additional force here include significant amounts of nutrients entering the Baltic with large continental rivers draining agriculturally transformed catchment areas (Wasmund and Uhlig, 2003; Wasmund and Siegel, 2008; HELCOM, 2009). The biological activity, including the ratio between photosynthesis and respiration in particular, determines the level and dynamics of $\mathrm{CO}_{2}$ partial pressure $\left(p \mathrm{CO}_{2}\right)$ in seawater and hence a strength and direction of $\mathrm{CO}_{2}$ exchange through the seawater/atmosphere interface. These are, most likely, the reasons behind the significant discrepancies in the $\mathrm{CO}_{2}$ air-sea

Published by Copernicus Publications on behalf of the European Geosciences Union. 


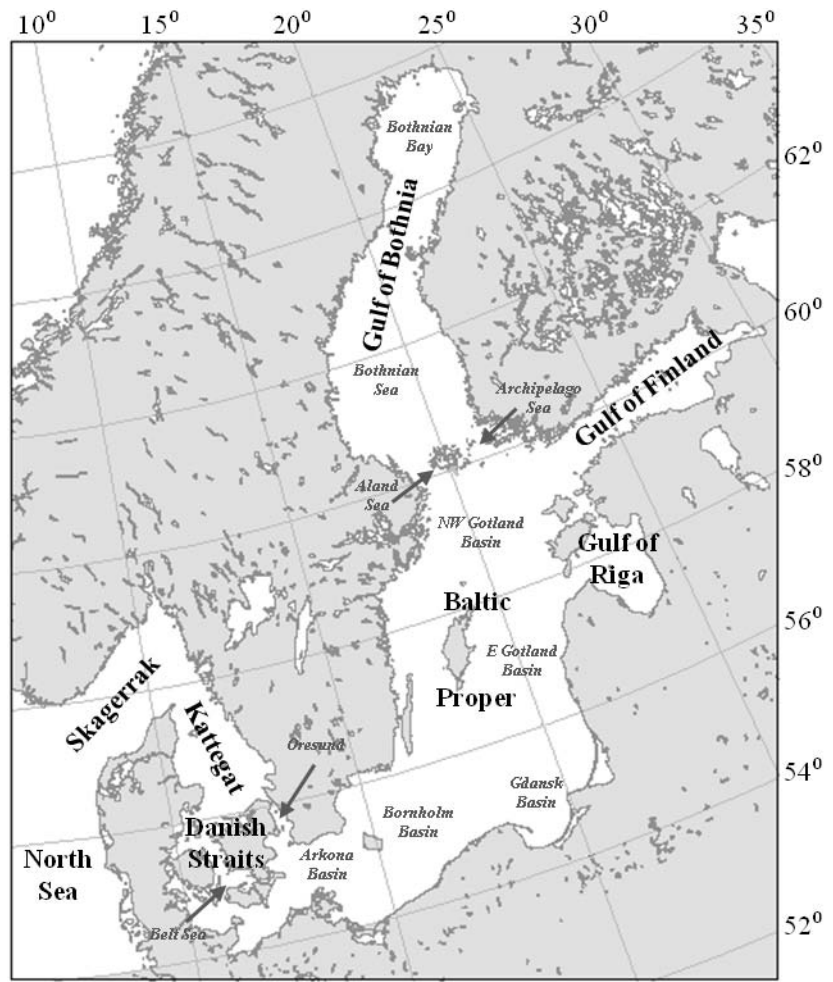

Fig. 1. Map of the Baltic Sea showing its division into natural basins and sub-basins (modified after Omstedt et al., 2009).

exchange results reported in the literature (Ohlson, 1990; Thomas and Schneider, 1999; Thomas et al., 2003; Algesten et al., 2004 and 2006; Kuss et al., 2006; Wesslander et al., 2010; Beldowski et al., 2010; Schneider et al., 2003). On the one hand, low productive and highly influenced by terrestrial organic carbon water of the Gulf of Bothnia is believed to be a $\mathrm{CO}_{2}$ source to the atmosphere (Algesten et al., 2004 and 2006). On the other hand, highly productive, open waters of the southern Baltic act as an effective sink of atmospheric $\mathrm{CO}_{2}$ (Ohlson, 1990; Thomas and Schneider, 1999; Thomas et al., 2003; Kuss et al., 2006; Chen and Borges, 2009). However, recent data (Wesslander et al., 2010) have identified the southern and central Baltic as a significant source of $\mathrm{CO}_{2}$ to the atmosphere as well.

The results reported above are based on the $p \mathrm{CO}_{2}$ measurements made at stations located in the open waters of the Baltic Sea. The near-shore zones and areas adjacent to river mouths are often not included in the $p \mathrm{CO}_{2}$ measurements. However, these regions of the Baltic Sea could be of special importance for the $\mathrm{CO}_{2}$ cycling, since it has been demonstrated worldwide that the near-shore zones and river mouths are important sources of $\mathrm{CO}_{2}$ to the atmosphere (Frankignoulle et al., 1998; Borges, 2005; Chen and Borges, 2009; Liu et al., 2010a). This is due to the significant input of terrestrial carbon. The rivers flowing into the Baltic Sea drain an area that is more than four times larger than that of the sea itself. Moreover, the water volume the rivers supply an- nually to the Baltic Sea amounts to almost $2 \%$ of the total water volume of the sea (Lass and Matthäus, 2008).

Although numerous studies on $\mathrm{CO}_{2}$ exchange through the seawater/atmosphere interface have been performed in the Baltic Sea in comparison with other shelf seas, there is no straightforward understanding of the part played by the entire Baltic Sea in the $\mathrm{CO}_{2}$ air-sea exchange. There are discrepancies between reported results, even though they relate to the same area (Thomas and Schneider, 1999; Wesslander et al., 2010). Similarly, the other carbon inputs and outputs to and from the Baltic Sea, reported in the literature, are incomplete or require revision (Thomas et al., 2003 and 2010). The recent studies by Kuliński et al. (2011) and by Kuliński and Pempkowiak (2011) redefine the results of carbon exchange between the Baltic and the North Sea, and quantify carbon burial in the Baltic bottom sediments. Moreover, although the Baltic Sea carbon cycle is significantly influenced by the input of terrestrial carbon, calculations of carbon supply from land are still based on annual averages of water flow and carbon concentrations obtained as extrapolations of marine carbon concentrations against salinity (Thomas et al., 2003 and 2010).

These aspects were the motivation for the present study. The aim was to develop a state-of-the-art carbon budget for the entire Baltic Sea that would provide a comprehensive description of the boundary carbon fluxes. Based on both experimental and literature data (Pempkowiak and Kupryszewski, 1980; Granskog et al., 2005; Thomas et al., 2005, 2010; Algesten et al., 2006; Kuliński and Pempkowiak, 2008; Dzierzbicka-Głowacka et al., 2010; Kowalczuk et al., 2010), major carbon fluxes were selected for the present investigation. They include carbon exchange between the Baltic and the North Sea, river input, organic carbon burial in bottom sediments, atmospheric deposition, point sources (all terrestrial carbon loads other than those entering the Baltic Sea from rivers), fisheries, and net $\mathrm{CO}_{2} \mathrm{ex}-$ change between sea water and the atmosphere (Fig. 2). Since the net $\mathrm{CO}_{2}$ exchange is temporally and spatially highly variable, and the results reported in the literature are ambiguous (Thomas and Schneider, 1999; Algesten et al., 2006; Kuss et al., 2006; Wesslander et al., 2010), it was calculated using the mass balance approach. The mass balance is based on the assumption that a steady state occurs, as a result of which all carbon sinks and sources in the Baltic Sea balance one another. The mass balance approach is a minimal requirement to obtain a reliable, quantitative description of the carbon cycle in highly diverse ecosystems (Liu et al., 2010a). A similar method for quantifying $\mathrm{CO}_{2}$ exchange between the Baltic Sea and the atmosphere was used a decade ago and described by Thomas et al. (2010). Those authors identified the Baltic Sea as a sink for atmospheric $\mathrm{CO}_{2}$ amounting to $2.28 \mathrm{Tg} \mathrm{C} \mathrm{yr}^{-1}$. Since then, however, revised carbon fluxes in the Baltic Sea have been reported (Kuliński et al., 2011; Kuliński and Pempkowiak, 2011), and other corrected fluxes are reported here. 


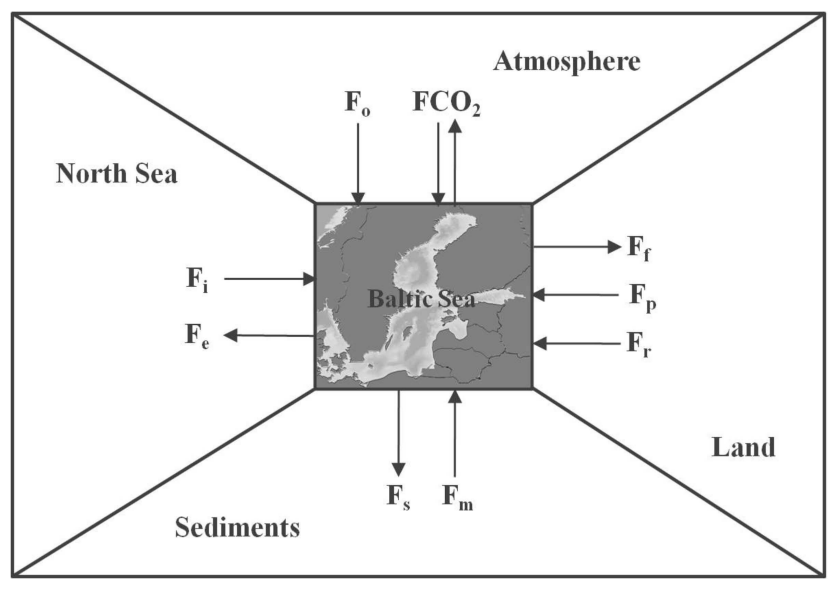

Fig. 2. Carbon sources and sinks in the Baltic Sea. Symbols: $F_{\mathrm{e}}$ - export to the North Sea, $F_{\mathrm{i}}$ - import from the North Sea, $F_{\mathrm{O}}-$ atmospheric deposition, $\mathrm{FCO}_{2}-$ net $\mathrm{CO}_{2}$ exchange between seawater and the atmosphere, $F_{\mathrm{f}}-$ fisheries, $F_{\mathrm{p}}$ - point sources, $F_{\mathrm{r}}-$ river input, $F_{\mathrm{s}}$ - accumulation in sediments, $F_{\mathrm{m}}$ - return flux from sediments to the water column.

\section{Materials and methods}

\subsection{Study area}

The Baltic Sea is a landlocked shelf sea connected to the North Sea only via the shallow and narrow Danish Straits (Fig. 1). Moreover, there are two sills at the entrance to the Baltic, the Drogden Sill and the Darss Sill, with respective maximum depths of 8 and $18 \mathrm{~m}$. These features restrict the exchange of water between the Baltic and the North Sea and permit the inflow of only large, episodic volumes (in excess of $100 \mathrm{~km}^{3}$ ) of highly saline and well oxygenated North Sea water. On the other hand there is a larger volume of river runoff ( $428 \mathrm{~km}^{3} \mathrm{yr}^{-1}$ on average). Almost $70 \%$ of this runoff enters the north-eastern Baltic, i.e. the Gulfs of Bothnia, Finland and Riga (Fig. 1). This gives rise to horizontal and vertical gradients of the sea's physical, chemical and ecological properties. There is a permanent halocline at $60-80 \mathrm{~m}$ depth separating the brackish surface water from the deep, more saline, water of the North Sea origin. This natural density barrier hinders the ventilation of deep water, resulting in conditions of permanent hypoxia or even anoxia at the sediment surface of the Baltic Sea deeps (Elken and Matthäus, 2008; Lass and Matthäus, 2008).

\subsection{Quantification of carbon fluxes}

In order to present the comprehensive carbon budget of the Baltic Sea the significant carbon inputs/outputs to/from the Baltic Sea were quantified based on the data available in literature as well as on our own studies. The considered carbon fluxes include: carbon exchange between the Baltic and the North Sea, river input, organic carbon burial in bottom sed- iments, atmospheric deposition, point sources (all terrestrial carbon loads other than those entering the Baltic Sea with rivers), fisheries, and net $\mathrm{CO}_{2}$ exchange between sea water and the atmosphere. Quantifications of some of them, being difficult to assess and simultaneously essential for the budget, are presented in separate papers and only conclusions from those studies are reported here. For example carbon exchange between the Baltic Sea and the North Sea and carbon burial in the bottom sediments were studied in details as presented in papers by Kuliński et al. (2011) and Kuliński and Pempkowiak (2011). The quantification of the other carbon fluxes including $\mathrm{CO}_{2}$ exchange through the Baltic seawater/atmosphere interface, calculated as a closing term of the carbon budget, are described here entirely.

All the investigated carbon fluxes were quantified on an annual timescale, irrespective of the temporal resolution used for the assessment. This was essential to balance the carbon inputs and outputs and to construct the carbon budget. The methodology used for the quantification of all the carbon fluxes that the presented Baltic carbon budget is composed of, as well as the results and conclusions obtained within this study are presented in the following sections of the manuscript.

\subsection{Carbon exchange between the Baltic Sea and the North Sea}

Carbon exchange between the Baltic Sea and the North Sea $\left(F_{\mathrm{e}}\right.$ and $\left.F_{\mathrm{i}}\right)$ was calculated as the product of water volume and carbon concentration (Eqs. 1 and 2). Using the results of experimental work performed at the Institute of Oceanology PAS (Kuliński, 2010) and literature data (Thomas and Schneider, 1999; Omstedt et al., 2004; Lass and Matthäus, 2008; Prowe et al., 2009), it was found that temporal resolutions of the variables should be finer than one week for concentrations of carbon species, and one day for water volumes and directions. Hence, three latitudinal transects in the Danish Straits were selected, for which hydrological data were supplied from the DMI-BSHcmod three-dimensional (3-D) ocean circulation model, which is the Danish Meteorological Institute (DMI) operational model. The "end members" method was used to separate the Baltic Sea and the North Sea water masses ( $V_{\mathrm{B}}$ and $V_{\mathrm{N}}$, respectively) in the bulk of water flowing across the transects. Simultaneously, the seasonal variability in inorganic (DIC) and organic (DOC) carbon concentrations was assessed separately for the Baltic Sea $\left(\mathrm{DIC}_{\mathrm{B}}\right.$ and $\left.\mathrm{DOC}_{\mathrm{B}}\right)$ and the North Sea $\left(\mathrm{DIC}_{\mathrm{N}}\right.$ and $\left.\mathrm{DOC}_{\mathrm{N}}\right)$ water masses. The details of the methods used for quantifying carbon exchange between the Baltic and the North Sea and the results used in this study are described in Kuliński et al. (2011).

$$
\begin{aligned}
& F_{\mathrm{e}}=V_{\mathrm{B}} \cdot\left(\mathrm{DIC}_{\mathrm{B}}+\mathrm{DOC}_{\mathrm{B}}\right) \\
& F_{\mathrm{i}}=V_{\mathrm{N}} \cdot\left(\mathrm{DIC}_{\mathrm{N}}+\mathrm{DOC}_{\mathrm{N}}\right)
\end{aligned}
$$




\subsubsection{Organic carbon burial in the bottom sediments}

Organic carbon burial $\left(F_{\mathrm{b}}\right)$ in the bottom sediments of the Baltic Sea was calculated as the difference between the organic carbon accumulated in the deep depositional areas of the Baltic Sea $\left(F_{\mathrm{S}}\right)$ and the organic matter losses due to longterm mineralization in sediments $\left(F_{\mathrm{m}}\right)($ Eq. 3$)$. The former was assessed from sediment accumulation rates $(\omega)$ obtained using the ${ }^{210} \mathrm{~Pb}$ method and validated against the ${ }^{137} \mathrm{Cs}$ distribution (Joshi and Shukla, 1991; Pempkowiak, 1991) and organic carbon concentrations in the sediments $\left(\mathrm{C}_{\mathrm{org}}\right)$ (Eq. 4). Carbon losses caused by the long-term mineralization were calculated from the dissolved inorganic carbon and dissolved organic carbon diffusive fluxes $\left(F_{\text {DIC }}\right.$ and $F_{\text {DOC }}$, respectively) from the sediment surface to the water column (Eq. 5). The details of organic carbon burial quantification in the Baltic Sea sediments are presented in Kuliński and Pempkowiak (2011).

$$
\begin{aligned}
& F_{\mathrm{b}}=F_{\mathrm{s}}-F_{\mathrm{m}} \\
& F_{\mathrm{s}}=\omega \cdot \mathrm{C}_{\mathrm{org}} \\
& F_{\mathrm{m}}=F_{\mathrm{DIC}}+F_{\mathrm{DOC}}
\end{aligned}
$$

\subsubsection{Riverine input}

The terrestrial carbon load to the Baltic Sea from rivers $\left(F_{\mathrm{r}}\right)$ was calculated as the product of individual river discharges $\left(R_{\mathrm{d}}\right)$ and carbon concentrations in river water - both total inorganic carbon and total organic carbon $\left(\mathrm{TIC}_{\mathrm{r}}\right.$ and $\mathrm{TOC}_{\mathrm{r}}$, respectively) - for the 63 largest Baltic Sea rivers (Eq. 6). The relevant data (monthly means of $R_{\mathrm{d}}, \mathrm{TIC}_{\mathrm{r}}$ and $\mathrm{TOC}_{\mathrm{r}}$ ) were taken from the database created and provided by the Baltic-C - a BONUS funded project. This database contains the results obtained by national monitoring programmes carried out by the Baltic Sea countries. Because of the lack of up-to-date data, the mean annual carbon loads for 6 rivers - the Koskenkyla, Kuivajoki, Lestijoki, Paimionjoki, Perhojoki and Sirrpujoki - were assessed for the period 19952000. In the case of the rivers Göta, Narva, Daugava and Neva, water flows were taken from the paper by Kuusisto et al. (2008). Moreover, the TIC and TOC concentrations data for the rivers Daugava and Neva were assumed to be similar to those found in adjacent rivers whose drainage basins have a similar geological structure (Voipio, 1981). In the case of the Daugava they were adapted from the River Neman, whereas for the River Neva, the mean TIC and TOC concentrations were the average of the concentrations measured in the Narew and the Virajoki.

$F_{\mathrm{r}} \sum R_{\mathrm{d}} \cdot\left(\mathrm{TIC}_{\mathrm{r}}+\mathrm{TOC}_{\mathrm{r}}\right)$

\subsubsection{Atmospheric deposition}

Atmospheric deposition $\left(F_{\mathrm{o}}\right)$ consists of two terms: dry deposition $\left(F_{\text {od }}\right)$ and wet deposition $\left(F_{\text {ow }}\right)($ Eq. 7$)$.

$F_{\mathrm{o}}=F_{\mathrm{od}}+F_{\mathrm{ow}}$
The literature data do not supply straightforward information relating to the dry deposition of carbon to the Baltic Sea. However, the dry deposition of carbon from the atmosphere is significantly lower than that attributed to wet deposition (Jurado et al., 2008). It was assumed that marine aerosols emitted from the Baltic Sea surface are redeposited in the same amounts on the water surface. Hence, only the wet deposition of carbon to the Baltic Sea is considered in the present study (Eq. 8):

$F_{\mathrm{o}}=F_{\mathrm{ow}}=P \cdot\left(\mathrm{C}_{\mathrm{o}}+\mathrm{C}_{\mathrm{i}}+\mathrm{C}_{\mathrm{b}}\right)$

where $P$ is the mean precipitation over the Baltic Sea, and $\mathrm{C}_{\mathrm{o}}, \mathrm{C}_{\mathrm{i}}$ and $\mathrm{C}_{\mathrm{b}}$ are the respective concentrations of organic, inorganic and black carbon in rain water.

The organic carbon load with wet atmospheric deposition to the Baltic Sea was calculated by fitting the values reported by Algesten et al. (2006) to the entire Baltic Sea surface area. Kuśmierczyk-Michulec et al. (2001) noted that black carbon concentrations were eight times lower than organic carbon concentrations in the aerosol samples collected over the Baltic. Since aerosols are a major source of organic carbon in rain water (Jurado et al., 2008), the same rate was used to calculate the black carbon load to the Baltic Sea derived from wet deposition.

Rainwater saturated with atmospheric $\mathrm{CO}_{2}$ was identified as a source of inorganic carbon input to the Baltic Sea with wet deposition. Henry's Law (Eq. 9) was used to calculate the $\mathrm{CO}_{2}$ concentration in rainwater (Ibanez et al., 2007):

$\mathrm{C}=K_{\mathrm{H}} \cdot p$

where $\mathrm{C}$ is a $\mathrm{CO}_{2}$ concentration in rainwater, $K_{\mathrm{H}}$ is a Henry's constant $\left(T=10^{\circ} \mathrm{C}\right.$ and $\left.1013 \mathrm{hPa}\right)$ and $p$ is a $\mathrm{CO}_{2}$ partial pressure in the atmosphere.

\subsubsection{Point sources}

The amount of carbon input to the Baltic Sea from point sources $\left(F_{\mathrm{p}}\right)$ was assessed using the HELCOM (2004) data. Since it was expressed in terms of $\mathrm{BOD}_{7}$ (biological oxygen demand), the conversion rate $(k)$ was applied according to the HELCOM (1983) to calculate the carbon mass (Eq. 10).

$F_{\mathrm{p}}=\mathrm{BOD}_{7} \cdot k^{-1} \quad(k=2.27)$

\subsubsection{Fisheries}

Fish landings are assumed to be a carbon sink. Recent data on total fish landings in the Baltic Sea $\left(F_{1}\right)$ were adapted from the ICES report of 2008. In accordance with Crabtree's (1995) results, a mean organic carbon concentration in the fish biomass $\left(\mathrm{C}_{\mathrm{f}}\right)$ amounting to $8.2 \%$ of the wet weight was used to recalculate fish landings as carbon mass removed from the Baltic Sea $\left(F_{\mathrm{f}}\right)($ Eq. 11):

$F_{\mathrm{f}}=F_{1} \cdot C_{\mathrm{f}}$ 


\subsection{6 $\mathrm{CO}_{2}$ exchange between the Baltic Sea and the atmosphere}

The net $\mathrm{CO}_{2}$ exchange between the Baltic Sea and the atmosphere $\left(F \mathrm{FO}_{2}\right)$ was calculated using the mass balance approach on the assumption that an equilibrium exists between carbon sources and sinks (Eq. 12). Hence, when carbon sources in the Baltic Sea are presented as positive values and carbon sinks as negative ones, the sum of the carbon fluxes should balance one another (Eq. 13). This enables the $\mathrm{FCO}_{2}$ direction and strength between the Baltic Sea and the atmosphere to be calculated (Eq. 14).

$$
\begin{aligned}
& \sum \text { carbon sources }=\sum \text { carbon sinks } \\
& F_{\mathrm{e}}+F_{\mathrm{i}}+F_{\mathrm{o}}+F \mathrm{CO}_{2}+F_{\mathrm{f}}+F_{\mathrm{p}}+F_{\mathrm{r}}+F_{\mathrm{m}}+F_{\mathrm{s}}=0 \\
& F \mathrm{CO}_{2}=F_{\mathrm{e}}+F_{\mathrm{i}}+F_{\mathrm{o}}+F_{\mathrm{f}}+F_{\mathrm{p}}+F_{\mathrm{r}}+F_{\mathrm{m}}+F_{\mathrm{s}}
\end{aligned}
$$

The uncertainty of the $\mathrm{FCO}_{2}(X)$ flux was calculated as the square root of the sum of squared errors of all the carbon sources and sinks $\left(x_{i}\right)$ (Eq. 15). The uncertainties of the individual carbon fluxes take into account both the representativeness of water flows and the seasonality of carbon concentrations.

$$
X=\left(\sum_{i} x_{i}^{2}\right)^{0.5}
$$

\section{Results}

All the results obtained in this study are presented according to the following scheme: positive values indicate carbon sources, negative ones indicate carbon sinks.

The carbon loads to the Baltic Sea from the 63 rivers investigated are listed in Table 1. These results exhibit a distinct discrepancy in the carbon loads and water flows between the Scandinavian (Sweden, Finland) and continental rivers (Poland, Lithuania, Latvia, Estonia and Russia). The former have higher TOC than TIC loads, in contrast to the results obtained for the continental rivers. The TOC fluxes in the Scandinavian rivers range from $0.5 \mathrm{Gg} \mathrm{yr}^{-1}\left(\mathrm{Gg}=10^{9} \mathrm{~g}\right)$ to $102.4 \mathrm{Gg} \mathrm{yr}^{-1}$ (rivers Ljusnan and Torne, respectively), and TIC loads range from $0.1 \mathrm{Gg} \mathrm{yr}^{-1}$ to $63.8 \mathrm{Gg} \mathrm{yr}^{-1}$ (rivers Sirppujoki and Göta, respectively). In the case of the continental rivers the ranges are from $75.5 \mathrm{Gg} \mathrm{yr}^{-1}$ (Odra) to $1209.5 \mathrm{Gg} \mathrm{yr}^{-1}$ (Neva) and from $384.5 \mathrm{Gg} \mathrm{yr}^{-1}$ (Narwa) to 1295.2 $\mathrm{Gg} \mathrm{yr}^{-1}$ (Neva) for TOC and TIC loads, respectively. Both TOC and TIC loads are higher in the continental rivers than in the Scandinavian. This results from the higher water flows in the continental rivers. The annual freshwater volume input with the continental rivers to the Baltic Sea fluctuates between $11.9 \mathrm{~km}^{3}$ and $77.6 \mathrm{~km}^{3}$ for the Neman and Neva, respectively. The same range for the Scandinavian rivers is between $0.1 \mathrm{~km}^{3}$ (the Sirppujoki and the Virojoki) and $18.1 \mathrm{~km}^{3}$ (the Göta).
The freshwater supply from all 63 rivers amounts to $345 \mathrm{~km}^{3} \mathrm{yr}^{-1}$, some $80 \%$ of the total river runoff to the Baltic Sea $\left(428 \mathrm{~km}^{3} \mathrm{yr}^{-1}\right)$ (Lass and Matthäus, 2008). Thus, assuming the results obtained to be representative for

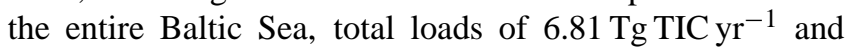

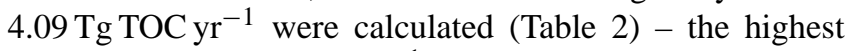
carbon source $\left(10.90 \mathrm{Tg} \mathrm{yr}^{-1}\right)$ in the carbon budget of the Baltic Sea (Fig. 3).

The second largest source of carbon to the Baltic Sea is the input from the North Sea $\left(3.91 \mathrm{Tg} \mathrm{yr}^{-1}\right.$; see Fig. 3 and Table 2). Almost $95 \%$ of this amount is inorganic carbon. However, carbon exchange between the Baltic and the North Sea is dominated by an export to the North Sea of $-9.70 \mathrm{Tg} \mathrm{yr}^{-1}$ of inorganic carbon and $-1.88 \mathrm{Tg} \mathrm{yr}^{-1}$ of organic carbon (Fig. 3; Table 2). The Baltic Sea is thus a net source of carbon $\left(-7.67 \mathrm{Tg} \mathrm{yr}^{-1}\right)$ for the North Sea.

The bottom sediments are yet another crucial carbon sink in the Baltic Sea (Fig. 3; Table 2), annually receiving $-3.87 \mathrm{Tg}$ of organic carbon. This amount needs to be corrected by the return carbon flux $\left(1.14 \mathrm{Tg} \mathrm{yr}^{-1}\right)$ originating from the long-term mineralization and hydrolysis of the organic matter deposited in the sediments. The bulk of the carbon returning to the water column (91\%) is dissolved inorganic carbon (DIC), indicating that the rate of mineralization exceeds that of hydrolysis of organic carbon in the sediments.

The contributions of atmospheric deposition, point sources and fisheries are less significant $(0.57,0.04$ and $-0.06 \mathrm{Tg} \mathrm{C} \mathrm{yr}^{-1}$, respectively; see Fig. 3 and Table 2).

The unbalanced amount of carbon, according to the definition given in Sect. 2.2.7, is attributed to the net $\mathrm{CO}_{2}$ exchange between the seawater and the atmosphere. The results (Fig. 3; Table 2) show that the Baltic Sea acts as a small source of $\mathrm{CO}_{2}$ to the atmosphere. On average, $1.05 \mathrm{Tg}$ of carbon are emitted annually to the atmosphere in the form of $\mathrm{CO}_{2}$, a result that is encumbered with an uncertainty of $\pm 1.71 \mathrm{Tg} \mathrm{yr}^{-1}$. Although this uncertainty exceeds the value of $\mathrm{FCO}_{2}$, one should remember that it makes up as little as $5.3 \%$ of the total carbon sources and sinks summed as absolute values.

\section{Discussion}

The carbon budget obtained in this work identifies the Baltic Sea as a region very much influenced by the surrounding drainage area. The total terrestrial carbon input is $10.94 \mathrm{TgC}^{-1}$ (Fig. 3; Table 2), of which only $0.04 \mathrm{Tg} \mathrm{C} \mathrm{yr}^{-1}$ is attributable to point sources; the remaining $10.90 \mathrm{Tg} \mathrm{C} \mathrm{yr}^{-1}$ enter the Baltic Sea with rivers. This amount is comparable to the results reported by Thomas et al. (2010),

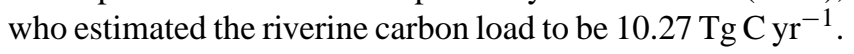
However, we see a significant difference when the organic carbon contribution is considered in the total carbon load supplied from rivers: riverine TOC is $37.5 \%$ in our study but only $20.5 \%$ as reported by Thomas et al. (2010). 
Table 1. Water flows, TIC and TOC loads for the 63 largest rivers entering the Baltic Sea. Carbon fluxes are expressed in Gg yr ${ }^{-1}$ $\left(\mathrm{Gg}=10^{9} \mathrm{~g}\right)$.

\begin{tabular}{|c|c|c|c|c|c|c|c|}
\hline & River & Country & Latitude & Longitude & $\begin{array}{r}\text { Water flow } \\
{\left[\mathrm{km}^{3} \mathrm{yr}^{-1}\right]}\end{array}$ & $\begin{array}{r}\text { TIC } \\
{\left[\mathrm{Gg} \mathrm{yr}^{-1}\right]}\end{array}$ & $\begin{array}{r}\text { TOC } \\
{\left[\mathrm{Gg} \mathrm{yr}^{-1}\right]}\end{array}$ \\
\hline 1 & Ahtava & Finland & $63^{\circ} 39^{\prime} \mathrm{N}$ & $22^{\circ} 49^{\prime} \mathrm{E}$ & 0.5 & 1.2 & 6.9 \\
\hline 2 & Ångermanälven & Sweden & $62^{\circ} 48^{\prime} \mathrm{N}$ & $17^{\circ} 56^{\prime} \mathrm{E}$ & 16.3 & 37.5 & 84.6 \\
\hline 3 & Ätran & Sweden & $56^{\circ} 53^{\prime} \mathrm{N}$ & $12^{\circ} 28^{\prime} \mathrm{E}$ & 1.8 & 7.0 & 19.3 \\
\hline 4 & Aura & Finland & $60^{\circ} 26^{\prime} \mathrm{N}$ & $22^{\circ} 14^{\prime} \mathrm{E}$ & 0.2 & 1.7 & 4.1 \\
\hline 5 & Botorpström & Sweden & $57^{\circ} 38^{\prime} \mathrm{N}$ & $16^{\circ} 34^{\prime} \mathrm{E}$ & 0.2 & 1.1 & 2.6 \\
\hline 6 & Daugava & Latvia & $57^{\circ} 03^{\prime} \mathrm{N}$ & $24^{\circ} 01^{\prime} \mathrm{E}$ & 20.8 & 1068.9 & 210.7 \\
\hline 7 & Delångersån & Sweden & $61^{\circ} 40^{\prime} \mathrm{N}$ & $17^{\circ} 12^{\prime} \mathrm{E}$ & 0.4 & 1.0 & 2.6 \\
\hline 8 & Emån & Sweden & $57^{\circ} 07^{\prime} \mathrm{N}$ & $16^{\circ} 30^{\prime} \mathrm{E}$ & 1.1 & 4.3 & 16.8 \\
\hline 9 & Eura & Finland & $61^{\circ} 13^{\prime} \mathrm{N}$ & $21^{\circ} 36^{\prime} \mathrm{E}$ & 0.2 & 0.9 & 2.7 \\
\hline 10 & Gide & Sweden & $63^{\circ} 19^{\prime} \mathrm{N}$ & $19^{\circ} 08^{\prime} \mathrm{E}$ & 0.9 & 1.0 & 9.2 \\
\hline 11 & Göta & Sweden & $57^{\circ} 41^{\prime} \mathrm{N}$ & $11^{\circ} 54^{\prime} \mathrm{E}$ & 18.1 & 63.8 & 80.5 \\
\hline 12 & Helgeån & Sweden & $55^{\circ} 51^{\prime} \mathrm{N}$ & $14^{\circ} 14^{\prime} \mathrm{E}$ & 1.5 & 7.3 & 27.0 \\
\hline 13 & Iijoki & Finland & $65^{\circ} 20^{\prime} \mathrm{N}$ & $25^{\circ} 16^{\prime} \mathrm{E}$ & 5.7 & 12.9 & 66.5 \\
\hline 14 & Indalsälven & Sweden & $62^{\circ} 30^{\prime} \mathrm{N}$ & $17^{\circ} 26^{\prime} \mathrm{E}$ & 13.9 & 61.1 & 57.0 \\
\hline 15 & Kalajoki & Finland & $64^{\circ} 17^{\prime} \mathrm{N}$ & $23^{\circ} 54^{\prime} \mathrm{E}$ & 1.1 & 2.6 & 26.9 \\
\hline 16 & Kalix & Sweden & $65^{\circ} 50^{\prime} \mathrm{N}$ & $23^{\circ} 11^{\prime} \mathrm{E}$ & 10.1 & 20.5 & 59.0 \\
\hline 17 & Kemijoki & Finland & $65^{\circ} 46^{\prime} \mathrm{N}$ & $24^{\circ} 27^{\prime} \mathrm{E}$ & 0.3 & 1.3 & 2.1 \\
\hline 18 & Kiiminki & Finland & $65^{\circ} 12^{\prime} \mathrm{N}$ & $25^{\circ} 17^{\prime} \mathrm{E}$ & 1.5 & 2.9 & 25.8 \\
\hline 19 & Kiskonjoki & Finland & $60^{\circ} 08^{\prime} \mathrm{N}$ & $23^{\circ} 01^{\prime} \mathrm{E}$ & 0.2 & 0.7 & 2.7 \\
\hline 20 & Kokemaenjoki & Finland & $61^{\circ} 33^{\prime} \mathrm{N}$ & $21^{\circ} 42^{\prime} \mathrm{E}$ & 7.0 & 28.0 & 75.0 \\
\hline 21 & Koskenkyla & Finland & $60^{\circ} 28^{\prime} \mathrm{N}$ & $25^{\circ} 58^{\prime} \mathrm{E}$ & 0.2 & 1.0 & 1.9 \\
\hline 22 & Kuivajoki & Finland & $65^{\circ} 34^{\prime} \mathrm{N}$ & $25^{\circ} 10^{\prime} \mathrm{E}$ & 0.5 & 1.3 & 7.5 \\
\hline 23 & Kymi Ahven & Finland & $60^{\circ} 29^{\prime} \mathrm{N}$ & $26^{\circ} 27^{\prime} \mathrm{E}$ & 5.8 & 21.9 & 46.2 \\
\hline 24 & Kymi Kokon & Finland & $60^{\circ} 29^{\prime} \mathrm{N}$ & $26^{\circ} 54^{\prime} \mathrm{E}$ & 5.1 & 17.9 & 38.5 \\
\hline 25 & Lagan & Sweden & $56^{\circ} 32^{\prime} \mathrm{N}$ & $12^{\circ} 56^{\prime} \mathrm{E}$ & 2.8 & 4.8 & 37.9 \\
\hline 26 & Lapuanjoki & Finland & $63^{\circ} 34^{\prime} \mathrm{N}$ & $22^{\circ} 28^{\prime} \mathrm{E}$ & 0.9 & 1.7 & 19.1 \\
\hline 27 & Lestijoki & Finland & $64^{\circ} 04^{\prime} \mathrm{N}$ & $23^{\circ} 37^{\prime} \mathrm{E}$ & 0.3 & 0.5 & 6.2 \\
\hline 28 & Ljungan & Sweden & $61^{\circ} 12^{\prime} \mathrm{N}$ & $17^{\circ} 08^{\prime} \mathrm{E}$ & 3.2 & 15.2 & 19.2 \\
\hline 29 & Ljungbyån & Sweden & $56^{\circ} 37^{\prime} \mathrm{N}$ & $16^{\circ} 14^{\prime} \mathrm{E}$ & 0.2 & 0.3 & 3.4 \\
\hline 30 & Ljusnan & Sweden & $61^{\circ} 12^{\prime} \mathrm{N}$ & $17^{\circ} 07^{\prime} \mathrm{E}$ & 0.2 & 0.9 & 0.5 \\
\hline 31 & Lule & Sweden & $65^{\circ} 35^{\prime} \mathrm{N}$ & $22^{\circ} 02^{\prime} \mathrm{E}$ & 16.1 & 31.6 & 44.4 \\
\hline 32 & Lyckebyån & Sweden & $56^{\circ} 11^{\prime} \mathrm{N}$ & $15^{\circ} 39^{\prime} \mathrm{E}$ & 0.2 & 0.4 & 3.8 \\
\hline 33 & Merikarvia & Finland & $61^{\circ} 49^{\prime} \mathrm{N}$ & $21^{\circ} 32^{\prime} \mathrm{E}$ & 0.6 & 0.9 & 11.7 \\
\hline 34 & Mörrumsån & Sweden & $56^{\circ} 09^{\prime} \mathrm{N}$ & $14^{\circ} 44^{\prime} \mathrm{E}$ & 0.9 & 1.7 & 12.8 \\
\hline 35 & Motala & Sweden & $58^{\circ} 37^{\prime} \mathrm{N}$ & $16^{\circ} 15^{\prime} \mathrm{E}$ & 3.2 & 33.0 & 24.3 \\
\hline 36 & Mustijoki & Finland & $60^{\circ} 20^{\prime} \mathrm{N}$ & $25^{\circ} 34^{\prime} \mathrm{E}$ & 0.2 & 1.3 & 3.6 \\
\hline 37 & Narpionjoki & Finland & $62^{\circ} 24^{\prime} \mathrm{N}$ & $21^{\circ} 17^{\prime} \mathrm{E}$ & 0.3 & 0.5 & 7.2 \\
\hline 38 & Narwa & Estonia & $59^{\circ} 28^{\prime} \mathrm{N}$ & $28^{\circ} 02^{\prime} \mathrm{E}$ & 12.7 & 384.5 & 190.9 \\
\hline 39 & Nemen & Lithuania & $55^{\circ} 18^{\prime} \mathrm{N}$ & $21^{\circ} 15^{\prime} \mathrm{E}$ & 11.9 & 609.1 & 123.4 \\
\hline 40 & Neva & Russia & $59^{\circ} 55^{\prime} \mathrm{N}$ & $30^{\circ} 13^{\prime} \mathrm{E}$ & 77.6 & 1295.2 & 1209.5 \\
\hline 41 & Nissan & Sweden & $56^{\circ} 39^{\prime} \mathrm{N}$ & $12^{\circ} 51^{\prime} \mathrm{E}$ & 1.6 & 3.0 & 24.5 \\
\hline 42 & Nyköpingsån & Sweden & $58^{\circ} 44^{\prime} \mathrm{N}$ & $17^{\circ} 01^{\prime} \mathrm{E}$ & 0.6 & 5.5 & 6.4 \\
\hline 43 & Odra & Poland & $53^{\circ} 40^{\prime} \mathrm{N}$ & $14^{\circ} 31^{\prime} \mathrm{E}$ & 13.1 & 431.8 & 75.5 \\
\hline 44 & Öre & Sweden & $63^{\circ} 31^{\prime} \mathrm{N}$ & $19^{\circ} 44^{\prime} \mathrm{E}$ & 1.1 & 1.2 & 13.7 \\
\hline 45 & Oulujoki & Finland & $65^{\circ} 01^{\prime} \mathrm{N}$ & $25^{\circ} 27^{\prime} \mathrm{E}$ & 8.9 & 17.4 & 87.3 \\
\hline 46 & Paimionjoki & Finland & $60^{\circ} 24^{\prime} \mathrm{N}$ & $22^{\circ} 38^{\prime} \mathrm{E}$ & 0.2 & 2.4 & 2.3 \\
\hline 47 & Perhojoki & Finland & $63^{\circ} 53^{\prime} \mathrm{N}$ & $23^{\circ} 08^{\prime} \mathrm{E}$ & 0.6 & 0.6 & 10.1 \\
\hline 48 & Pite & Sweden & $65^{\circ} 21^{\prime} \mathrm{N}$ & $21^{\circ} 19^{\prime} \mathrm{E}$ & 5.5 & 8.9 & 22.4 \\
\hline 49 & Porvoonjoki & Finland & $60^{\circ} 22^{\prime} \mathrm{N}$ & $25^{\circ} 39^{\prime} \mathrm{E}$ & 0.4 & 3.6 & 5.5 \\
\hline 50 & Pyhajoki & Finland & $64^{\circ} 29^{\prime} \mathrm{N}$ & $24^{\circ} 12^{\prime} \mathrm{E}$ & 1.0 & 2.3 & 20.0 \\
\hline 51 & Råne & Sweden & $65^{\circ} 49^{\prime} \mathrm{N}$ & $22^{\circ} 21^{\prime} \mathrm{E}$ & 1.4 & 2.1 & 11.7 \\
\hline 52 & Rickleån & Sweden & $64^{\circ} 04^{\prime} \mathrm{N}$ & $20^{\circ} 56^{\prime} \mathrm{E}$ & 0.5 & 0.7 & 5.8 \\
\hline 53 & Rönneån & Sweden & $56^{\circ} 16^{\prime} \mathrm{N}$ & $12^{\circ} 50^{\prime} \mathrm{E}$ & 0.4 & 5.4 & 4.1 \\
\hline 54 & Siikajoki & Finland & $64^{\circ} 51^{\prime} \mathrm{N}$ & $24^{\circ} 42^{\prime} \mathrm{E}$ & 1.4 & 3.1 & 29.3 \\
\hline 55 & Simojoki & Finland & $65^{\circ} 37^{\prime} \mathrm{N}$ & $25^{\circ} 02^{\prime} \mathrm{E}$ & 1.5 & 3.6 & 20.3 \\
\hline 56 & Sirppujoki & Finland & $60^{\circ} 53^{\prime} \mathrm{N}$ & $21^{\circ} 26^{\prime} \mathrm{E}$ & 0.1 & 0.1 & 1.1 \\
\hline 57 & Skellefte & Sweden & $64^{\circ} 42^{\prime} \mathrm{N}$ & $21^{\circ} 09^{\prime} \mathrm{E}$ & 3.4 & 6.0 & 8.2 \\
\hline 58 & Torne & Sweden & $65^{\circ} 49^{\prime} \mathrm{N}$ & $24^{\circ} 09^{\prime} \mathrm{E}$ & 14.2 & 28.9 & 102.4 \\
\hline 59 & Ume & Sweden & $63^{\circ} 45^{\prime} \mathrm{N}$ & $20^{\circ} 19^{\prime} \mathrm{E}$ & 14.9 & 35.9 & 63.8 \\
\hline 60 & Uskela & Finland & $60^{\circ} 22^{\prime} \mathrm{N}$ & $23^{\circ} 04^{\prime} \mathrm{E}$ & 0.2 & 1.4 & 2.6 \\
\hline 61 & Vantaa & Finland & $60^{\circ} 13^{\prime} \mathrm{N}$ & $24^{\circ} 59^{\prime} \mathrm{E}$ & 0.6 & 4.7 & 8.9 \\
\hline & Virojoki & Finland & $60^{\circ} 34^{\prime} \mathrm{N}$ & $27^{\circ} 43^{\prime} \mathrm{E}$ & 0.1 & 0.4 & 2.5 \\
\hline \multirow[t]{2}{*}{63} & Vistula & Poland & $54^{\circ} 21^{\prime} \mathrm{N}$ & $18^{\circ} 57^{\prime} \mathrm{E}$ & 28.5 & 1168.1 & 175.6 \\
\hline & Total & & & & 344.9 & 5486.6 & 3297.9 \\
\hline
\end{tabular}




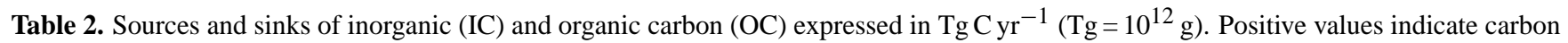
sources, negative ones indicate carbon sinks. Carbon loads are presented with their uncertainties $(X)$ calculated as the square root of the sum of squared errors of individual factors.

\begin{tabular}{|c|c|c|c|c|c|c|c|}
\hline \multirow[t]{2}{*}{ Carbon flux } & \multicolumn{2}{|c|}{ Sources } & \multicolumn{2}{|c|}{ Sinks } & \multicolumn{2}{|c|}{ Sum } & \multirow[t]{2}{*}{ Total $\pm X$} \\
\hline & $\mathrm{IC} \pm X$ & $\mathrm{OC} \pm X$ & $\mathrm{IC} \pm X$ & $\mathrm{OC} \pm X$ & $\mathrm{IC} \pm X$ & $\mathrm{OC} \pm X$ & \\
\hline Rivers & $6.81 \pm 0.98$ & $4.09 \pm 0.77$ & & & $6.81 \pm 0.98$ & $4.09 \pm 0.77$ & $10.90 \pm 1.25$ \\
\hline Baltic Sea/North Sea & $3.70 \pm 0.06$ & $0.21 \pm 0.02$ & $-9.70 \pm 0.14$ & $-1.88 \pm 0.22$ & $-6.00 \pm 0.15$ & $-1.67 \pm 0.22$ & $-7.67 \pm 0.27$ \\
\hline Sediments & $1.04 \pm 0.29$ & $0.10 \pm 0.03$ & & $-3.87 \pm 1.05$ & $1.04 \pm 0.29$ & $-3.77 \pm 1.05$ & $-2.73 \pm 1.12$ \\
\hline Atmospheric deposition & $0.06 \pm 0.02$ & $0.51^{1} \pm 0.07$ & & & $0.06 \pm 0.02$ & $0.51^{1} \pm 0.07$ & $0.57 \pm 0.07$ \\
\hline Point sources & & $0.04 \pm 0.00^{2}$ & & & & $0.04 \pm 0.00^{2}$ & $0.04 \pm 0.00^{2}$ \\
\hline Fisheries & & & & $-0.06 \pm 0.00^{2}$ & & $-0.06 \pm 0.00^{2}$ & $-0.06 \pm 0.00^{2}$ \\
\hline Net $\mathrm{CO}_{2}$ exchange & & & $-1.05 \pm 1.71$ & & $-1.05 \pm 1.71$ & & $-1.05 \pm 1.71$ \\
\hline Total & $11.61 \pm 1.02$ & $4.95 \pm 0.77$ & $-10.75 \pm 1.71$ & $-5.81 \pm 1.07$ & $0.86 \pm 2.00$ & $-0.86 \pm 1.32$ & \\
\hline
\end{tabular}

${ }^{1}$ The sum of organic carbon $\left(0.45 \mathrm{Tg} \mathrm{C} \mathrm{yr}^{-1}\right)$ and black carbon $\left(0.06 \mathrm{Tg} \mathrm{Cyr}^{-1}\right)$ loads.

2 The notation $\pm 0.00 \mathrm{Tg} \mathrm{Cyr}^{-1}$ means uncertainty lower than $0.005 \mathrm{Tg} \mathrm{C} \mathrm{yr}^{-1}$.

On the other hand the results obtained in the present study point unequivocally to two crucial carbon sinks in the Baltic Sea: net export to the North Sea $\left(-7.67 \mathrm{Tg} \mathrm{C} \mathrm{yr}^{-1}\right.$; Kuliński et al., 2011) and burial in the bottom sediments (2.73 $\mathrm{Tg} \mathrm{C} \mathrm{yr}^{-1}$; Kuliński and Pempkowiak, 2011) (Fig. 3; Table 2). The former amounts to $56 \%$ and $77 \%$, respectively, of the estimates reported by Thomas et al. (2003 and 2010). When the individual carbon fluxes are analysed in detail, the reasons for these discrepancies become clear. Carbon fluxes through the Danish Straits are highly dependent on the water flows. In both previous estimates (Thomas et al., 2003 and 2010), the water export from and import to the Baltic Sea were higher than the flows established in our study (Kuliński and Pempkowiak, 2011). Moreover, in contrast to previous papers (Thomas et al., 2003 and 2010), we considered the seasonality of both water flows and carbon concentrations (Kuliński and Pempkowiak, 2011).

The other important carbon sink in the Baltic Sea is the export of organic matter to the bottom sediments. According to the results obtained by Kuliński and Pempkowiak (2011), $-2.73 \mathrm{TgC}^{-1}$ are buried in the deep depositional basins of the Baltic Sea (Fig. 3; Table 2). This is comparable to the results of Thomas et al. (2010), who reported $-2.64 \mathrm{Tg} \mathrm{C} \mathrm{yr}^{-1}$. However, since the data of Thomas et al. (2010) are based on sediment accumulation rates and carbon concentrations in the sediments, they do not take into account carbon loss during the early diagenesis. Kuliński and Pempkowiak (2011) demonstrated that almost $30 \%$ of organic matter recently accumulated in the Baltic bottom sediments is released back to the water column as dissolved carbon species. Moreover, it is suggested that mineralization and hydrolysis of the organic matter accumulated in sediments goes on for as long as $60 \mathrm{yr}$ after the deposition. Thus, the return carbon flux should be definitely taken into account when the carbon budget is assessed.

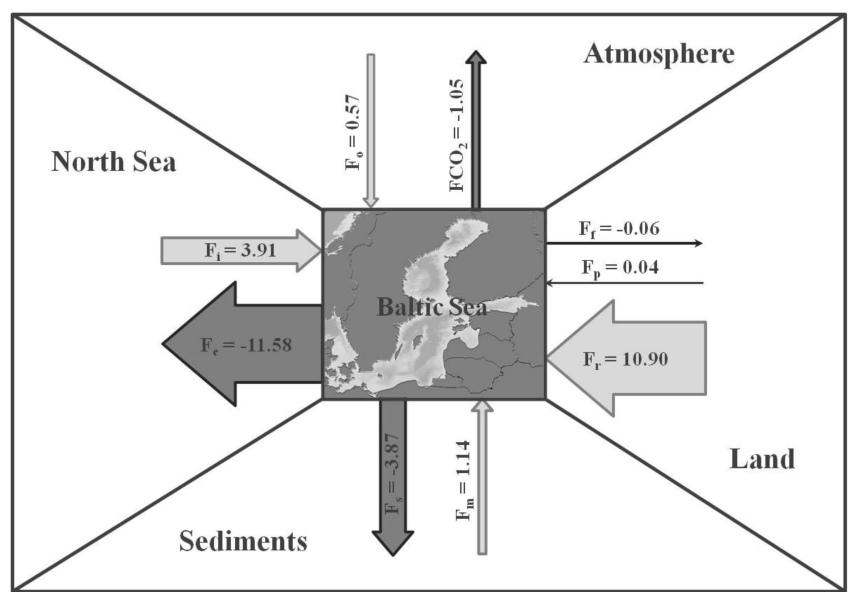

Fig. 3. Carbon budget of the Baltic Sea. Sources are marked in green (positive values), whereas sinks are marked in blue (negative values). Symbols: $F_{\mathrm{e}}-$ export to the North $\mathrm{Sea}, F_{\mathrm{i}}-$ import from the North Sea, $F_{\mathrm{O}}$ - atmospheric deposition, $F_{\mathrm{CO}_{2}}-$ net $\mathrm{CO}_{2}$ exchange between seawater and the atmosphere, $F_{\mathrm{f}}-$ fisheries, $F_{\mathrm{p}}-$ point sources, $F_{\mathrm{r}}$ - river input, $F_{\mathrm{s}}-$ accumulation in sediments, $F_{\mathrm{m}}$ - return flux from sediments to the water column. All carbon fluxes are expressed in $\mathrm{Tg} \mathrm{yr}^{-1}\left(\mathrm{Tg}=10^{12} \mathrm{~g}\right)$.

Although the other carbon sources and sinks are of minor importance (Fig. 3; Table 2), their quantification may be decisive for the quality of the whole carbon budget. We assessed the carbon source from atmospheric deposition as a product of precipitation and carbon concentration in rain water. We find this approach more accurate than that suggested by Thomas et al. (2010), where the precipitation used for the calculations was reduced by evaporation. Consequently, our result is higher $\left(0.57 \mathrm{Tg} \mathrm{Cyr}^{-1}\right)$ than the $0.24 \mathrm{Tg} \mathrm{C} \mathrm{yr}^{-1}$ reported by Thomas et al. (2010). 
Table 3. Comparison of the $\mathrm{FCO}_{2}$ results obtained with the literature data reported for the Baltic Sea. Positive values of $F C \mathrm{CO}_{2}$ indicate $\mathrm{CO}_{2}$ sequestration in seawater, whereas negative ones indicate emission of $\mathrm{CO}_{2}$ to the atmosphere. The Baltic Sea basins presented in the table are shown on Fig. 1.

\begin{tabular}{|c|c|c|}
\hline Region & $\begin{array}{r}F_{C_{2}} \\
{\left[\mathrm{~g} \mathrm{C} \mathrm{m}^{-2} \mathrm{yr}^{-1}\right]}\end{array}$ & Reference \\
\hline Baltic Sea & -2.7 & Present study \\
\hline Baltic Proper + Gulf of Finland + Gulf of Riga & 9.0 & $\begin{array}{l}\text { Present study based on the results } \\
\text { of Algesten et al. (2006) }\end{array}$ \\
\hline Baltic Sea & 2.3 & Thomas et al. (2010) \\
\hline Baltic Proper + Gulf of Finland + Gulf of Riga & 13.2 & Ohlson (1990) \\
\hline Baltic Proper + Gulf of Finland + Gulf of Riga & 10.8 & Thomas and Schneider (1999) \\
\hline Arkona Basin & 36.0 & Kuss et al. (2006) \\
\hline East Gotland Basin & -19.7 & Wesslander et al. (2010) \\
\hline Bornholm Basin & -28.1 & Wesslander et al. (2010) \\
\hline Gulf of Bothnia & -37.2 & Algesten et al. (2004) \\
\hline Gulf of Bothnia & -35.4 & Algesten et al. (2006) \\
\hline
\end{tabular}

Apart from the sources and sinks of total carbon, our carbon budget provides a detailed description of the organic and inorganic carbon fluxes. These data are significant since the trophic status of marine areas can be assessed using the organic carbon balance. Autotrophic areas are net producers of organic carbon, whereas heterotrophic areas are net consumers (Gattuso, 1998; Thomas et al., 2005). Thus, on the basis of the organic and inorganic carbon balance (Table 2), the Baltic Sea can be characterized as a heterotrophic marine system. However, it needs to be borne in mind that this is the net state of the entire sea. Generally, in stratified systems like the Baltic Sea, autotrophic processes dominate in the upper, euphotic zone, whereas heterotrophic ones are dominant in the subsurface layer (Thomas et al., 2005; Bozec et al., 2005).

The results obtained in the present study identify the entire Baltic Sea as a source of $\mathrm{CO}_{2}$ to the atmosphere. When the calculated $\mathrm{FCO}_{2}\left(-1.05 \mathrm{Tg} \mathrm{Cyr}^{-1}\right)$ is divided by the Baltic surface area of $3.85 \times 10^{5} \mathrm{~km}^{2}$ (excluding the Kattegat), we obtain mean $\mathrm{CO}_{2}$ emission of $-2.7 \mathrm{~g} \mathrm{C} \mathrm{m}^{-2} \mathrm{yr}^{-1}$ $\left(-9.9 \mathrm{~g} \mathrm{CO}_{2} \mathrm{~m}^{-2} \mathrm{yr}^{-1}\right)$. This finding is significant, since no report presented so far have yielded an average result for the entire Baltic Sea (Table 3; Ohlson; 1990; Thomas and Schneider, 1999; Algesten et al., 2004 and 2006; Kuss et al., 2006; Wesslander et al., 2010; Thomas et al., 2010). The biggest discrepancy concerns the status of the Baltic Proper, where the mean $\mathrm{FCO}_{2}$ ranges from $36.0 \mathrm{~g} \mathrm{C} \mathrm{m}^{-2} \mathrm{yr}^{-1}$ (Kuss et al., 2006) to $-28.1 \mathrm{~g} \mathrm{C} \mathrm{m}^{-2} \mathrm{yr}^{-1}$ (Wesslander et al., 2010), values respectively identifying these areas as a sink for atmospheric $\mathrm{CO}_{2}$ and a source of $\mathrm{CO}_{2}$ to the atmosphere. More coherent data are reported for the Gulf of Bothnia, defining this region as an evident $\mathrm{CO}_{2}$ source (Table 3; Algesten et al., 2004 and 2006). Based on these reports and taking into consideration the results of this study, the Baltic Proper together with the gulfs of Finland and Riga (Fig. 1) act as a
$\mathrm{CO}_{2}$ sink. When the most recent $\mathrm{FCO}_{2}$ data for the entire Gulf of Bothnia $\left(-3.61 \mathrm{Tg} \mathrm{C} \mathrm{yr}^{-1}\right)$ (Algesten et al., 2006) is used in this calculation, the mean $\mathrm{FCO}_{2}$ in the remaining part of the Baltic Sea area amounts to $2.56 \mathrm{TgC}^{-1}$ or $9.0 \mathrm{~g} \mathrm{C} \mathrm{m}^{-2} \mathrm{yr}^{-1}$. This result is close to that reported by Thomas and Schneider (1999) but more than $30 \%$ lower than the one reported by Ohlson (1990) (Table 3). Moreover, it is contrary to the findings of Wesslander et al. (2010), who report respective emissions of $\mathrm{CO}_{2}$ to the atmosphere from both the East Gotland Basin and the Bornholm Basin (Fig. 1) of -19.7 and $-28.1 \mathrm{~g} \mathrm{C} \mathrm{m}^{-2} \mathrm{yr}^{-1}$ (Table 3).

It is unlikely that this carbon budget for the Baltic Sea will not evolve in the next few decades. Several studies report the changes that may occur within the Baltic Sea region, most of them are induced by global climate changes (e.g. Graham, 2004; Meier, 2006; Graham et al., 2007, 2008). The expected total runoff change to 2100 ranges from -2 to $15 \%$ of the present flow according to the different climate scenarios (Graham, 2004; Graham et al., 2008). Studies performed on Swedish rivers (Smith et al., 2008) indicate that 71-97\% of the carbon load is explained by the water volume. Thus, it is very likely that the change in river runoff to the Baltic Sea will result in a change of terrestrial carbon input. Since the carbon entering the Baltic Sea from rivers is the largest source of carbon to the Baltic Sea, such changes may significantly contribute to the functioning of the entire Baltic Sea carbon system. However, the greatest unknown factor still remains the future input of nutrients to the Baltic Sea, which is the basic force driving the biological pump.

Simultaneously, as a consequence of the river runoff increase, outflows of the Baltic Sea water to the North Sea will increase and inflows of highly saline North Sea water will decrease (Cyberski and Wróblewski, 2000). Thus, some part of the additional terrestrial carbon load will be compensated by the increased carbon export to the North Sea and the reduced 
Table 4. Comparison of the $\mathrm{FCO}_{2}$ results calculated for the Baltic Sea with the literature data for other shelf seas. Positive values of the $\mathrm{FCO}_{2}$ indicate $\mathrm{CO}_{2}$ sequestration in seawater, whereas negative ones indicate emission of $\mathrm{CO}_{2}$ to the atmosphere.

\begin{tabular}{lrl}
\hline Region & $F \mathrm{CO}_{2}\left[\mathrm{~g} \mathrm{C} \mathrm{m}^{-2} \mathrm{yr}^{-1}\right]$ & Reference \\
\hline Arabian Sea & -10.8 & Goyet et al. (1998) \\
Baltic Sea & -2.7 & Present study \\
Baltic Proper + Gulf of Finland & 9.0 & Present study based on the results by \\
+ Gulf of Riga & & Algesten et al. (2006) \\
Barents Sea & 6.6 & Fransson et al. (2001) \\
Barents Sea & 43.2 & Borges et al. (2005) \\
Bering Sea & 51.6 & Walsh and Dieterle (1994) \\
Bering Sea & -56.4 & Fransson et al. (2006) \\
Chukchi Sea & 57.6 & Bates (2006) \\
Chukchi Sea & 37.2 & Kaltin and Anderson (2005) \\
North Sea & -26.4 & Bozec et al. (2005) \\
North Sea & 16.5 & Thomas et al. (2005) \\
North Sea (southern part) & -9.4 & Prowe et al. (2009) \\
North Sea (northern part) & 24.7 & Prowe et al. (2009) \\
Sea of Japan & 45.6 & Cai et al. (2006) \\
Sea of Okhotsk & 10.0 & Wakita et al. (2003) \\
South China Sea & -15.6 & Zhai et al. (2005) \\
South China Sea & 12.0 & Chen et al. (2003) \\
Yellow Sea & 24.0 & Chen and Borges (2009) \\
\hline
\end{tabular}

carbon import from the North Sea. There is still much debate on the consequences of the predicted lower frequency of the North Sea water inflows (Gerlach, 1994; Meier, 2006; Graham et al., 2008). On one hand a salinity decrease in the whole water column together with the simultaneous maintenance of vertical stratification is expected (Meier, 2006; Graham et al., 2008). On the other hand it is suggested that the halocline will drop to a lower depth (Gerlach, 1994; Graham et al., 2008). This may change the near-bottom redox conditions in parts of the depositional areas, with the consequent liberation of buried carbon resulting from the increased mineralization.

Comparison of the results obtained in this study with the findings reported for other shelf seas identifies the Baltic Sea as a basin with a close to neutral balance of $\mathrm{CO}_{2}$ exchange between seawater and the atmosphere (Table 4). Worldwide investigations show that $\mathrm{FCO}_{2}$ may be highly diverse in time and space within the same shelf sea. Some parts of the basin may act as efficient sinks for atmospheric $\mathrm{CO}_{2}$, whilst others are simultaneously a source of $\mathrm{CO}_{2}$ to the atmosphere. This feature justifies the use of the mass balance method for determining $\mathrm{FCO}_{2}$ for entire seas or at least for the verification of assessments based on local $p \mathrm{CO}_{2}$ and/or DIC and alkalinity measurements. Even though the $\mathrm{FCO}_{2}$ quantifications based on the $p \mathrm{CO}_{2}$ measurements are very sensitive to the transfer velocity parameterization, they usually are the most accurate. However this approach requires high spatial and temporal resolutions of the field measurements. On the other hand the mass balance approach is not a direct method of quantitatively assessing the $\mathrm{CO}_{2}$ exchange between the ma- rine environment and the atmosphere, and such $\mathrm{FCO}_{2}$ results are burdened with a relatively high uncertainty. Although this method can be used conveniently in large scale assessments, since it describes an average state of the environment. Thus, applying more than one method might be essential for the comprehensive studies of the $\mathrm{CO}_{2}$ transfer through the seawater/atmosphere interface, especially in highly diverse ecosystems. The carbon budget calculated for the North Sea (Thomas et al., 2005) shows that calculated carbon inputs and outputs are well balanced, so that it is possible to calculate one missing carbon flux when all the others have been calculated correctly, especially in enclosed or semi-enclosed shelf seas where the hydrological conditions are easier to define. Moreover, the carbon budget provides a qualitative and quantitative assessment of boundary conditions, which become crucial for understanding the carbon cycle in enclosed ecosystems such as the Baltic Sea.

\section{Conclusions}

The carbon budget of the Baltic Sea is highly influenced by the terrestrial carbon input. The largest carbon source to the

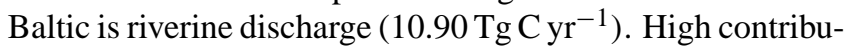
tion in this carbon load constitutes organic fraction amounting to $37.5 \%$ of the total discharge. Considerable terrestrial organic carbon load together with organic carbon originating from primary production cause the Baltic Sea a basin of at least 3-5 times higher organic carbon concentrations in seawater than these reported for the North Sea or for the North 
Atlantic Ocean. This feature, strengthened with net water export to the North Sea, results in much higher organic carbon export from the Baltic to the North Sea $\left(-1.88 \mathrm{Tg} \mathrm{C} \mathrm{yr}^{-1}\right)$ than its import in the opposite direction $\left(0.21 \mathrm{TgC} \mathrm{yr}^{-1}\right)$. The net export of carbon is noticed for the inorganic species as well ( $\left.-6.00 \mathrm{Tg} \mathrm{Cyr}^{-1}\right)$. In consequence the Baltic Sea becomes a significant carbon source for the North Sea amounting to $-7.67 \mathrm{Tg} \mathrm{Cyr}^{-1}$. Sediments are the second largest carbon sink in the Baltic Sea, where annually $-2.73 \mathrm{Tg} C$ is buried. The other carbon fluxes quantified in this study are: atmospheric deposition, point sources and fisheries at $0.57,0.04$ and $-0.06 \mathrm{Tg} \mathrm{Cyr}^{-1}$, respectively. The net $\mathrm{CO}_{2}$ exchange through the seawater/atmosphere interface computed as a closing term of the carbon budget point is emission to the atmosphere at $-1.05 \mathrm{Tg} \mathrm{C} \mathrm{yr}^{-1}$ or $-2.7 \mathrm{~g} \mathrm{C} \mathrm{m}^{-2} \mathrm{yr}^{-1}$. This result loaded with the uncertainty of $\pm 1.71{\mathrm{TgC} \mathrm{yr}^{-1} \text { or }}^{-1}$ $\pm 4.4 \mathrm{~g} \mathrm{C} \mathrm{m}^{-2} \mathrm{yr}^{-1}$ identifies the Baltic as a weak source of $\mathrm{CO}_{2}$.

Acknowledgements. The study was financially supported by the Polish Ministry of Science and Higher Education (BALTEX/09/2010/0), Baltic-C - the BONUS funded project and the Institute of Oceanology PAS statutory activity nr II.2.5.

Edited by: G. Herndl

\section{References}

Algesten, G., Wikner, J., Sobek, S., Tranvik, L. J., and Jansson, M.: Seasonal variation of $\mathrm{CO}_{2}$ saturation in the Gulf of Bothnia: indications of marine net heterotrophy, Global Biogeochem. Cy., 18, GB4021, doi:10.1029/2004GB002230, 2004.

Algesten, G., Brydsten, L., Jonsson, P., Kortelainen, P., Löfgren, S., Rahm, L., Räike, A., Sobek, S., Tranvik, L., Wikner, J., and Jansson, M.: Organic carbon budget for the Gulf of Bothnia, J. Marine Syst., 63, 155-161, 2006.

Andersson, A. J. and Mackenzie, F. T.: Shallow-water oceans: a source or sink of atmospheric $\mathrm{CO}_{2}$ ?, Front. Ecol. Environ., 2, 348-353, 2004.

Bates, N. R.: Air-sea $\mathrm{CO}_{2}$ fluxes and the continental shelf pump of carbon in the Chukchi Sea adjacent to the Arctic Ocean, J. Geophys. Res., 111, C10013, doi:10.1029/2005JC003083, 2006.

Beldowski J., Löffler, A., Schneider, B., and Joensuu, L.: Distribution and biogeochemical control of total $\mathrm{CO}_{2}$ and alkalinity in the Baltic Sea, J. Marine Syst., 81, 252-259, 2010.

Borges A. V.: Do We Have Enough Pieces of the Jigsaw to Integrate $\mathrm{CO}_{2}$ Fluxes in the Coastal Ocean?, Estuaries, 28, 3-27, 2005.

Borges, A. V., Delille, B., and Frankignoulle, M.: Budgeting sinks and sources of $\mathrm{CO}_{2}$ in the coastal ocean: diversity of ecosystems counts, Geophys. Res. Lett., 32, L14601, doi:10.1029/2005GL023053, 2005.

Bozec, Y., Thomas, H., Elkalay, K., and de Baar, H. J. W.: The continental shelf pump for $\mathrm{CO}_{2}$ in the North Sea-evidence from summer observation, Mar. Chem., 93, 131-147, 2005.

Crabtree, R. E.: Chemical composition and energy content of deepsea demersal fishes from tropical and temperate regions of the western North Atlantic, B. Mar. Sci., 56, 434-449, 1995.
Cai, W.-J., Dai, M. H., and Wang, Y. C.: Air-sea exchange of carbon dioxide in ocean margins: a province-based synthesis, Geophys. Res. Lett., 33, L12603, doi:10.1029/2006GL026219, 2006.

Chen, C.-T. A. and Borges, A. V.: Reconciling opposing views on carbon cycling in the coastal ocean: Continental shelves as sinks and near-shore ecosystems as sources of atmospheric $\mathrm{CO}_{2}$, Deep-Sea Res. Pt. II, 56, 578-590, 2009.

Chen, C.-T. A., Liu, K.-K., and Macdonald, R.: Continental Margin Exchanges, in: Ocean Biogeochemistry, edited by: Fasham, M. J. R., Springer-Verlag, Berlin, 53-97, 2003.

Cyberski, J., Wróblewski, A., and Stewart, J.: Riverine water inflows and the Baltic Sea water volume 1901-1990, Hydrol. Earth Syst. Sci., 4, 1-11, doi:10.5194/hess-4-1-2000, 2000.

Dippner, J. W., Vuorinen, I., Daunys, D., Flinkman, J., Halkka, A., Köster, F. W., Lehikoinen, E., MacKenzie, B. R., Möllmann, C., Mohlenberg, F., Olenin, S., Schiedek, D., Skov, H., and Wasmund, N.: Climate-related Marine Ecosystem Change, in: Assessment of Climate Change for the Baltic Sea Basin, edited by: The BACC Author Team, Springer-Verlag, Berlin, 309-377, 2008.

Dzierzbicka-Głowacka, L., Kuliński, K., Maciejewska, A., Jakacki, J., and Pempkowiak, J.: Particulate organic carbon in the southern Baltic Sea: numerical simulations and experimental data, Oceanologia, 52, 621-648, 2010.

Elken, J. and Matthäus, W.: Baltic Sea Oceanography, in: Assessment of Climate Change for the Baltic Sea Basin, edited by: The BACC Author Team, Springer-Verlag, Berlin, 379-386, 2008.

Frankignoulle, M., Abril, G., Borges, A., Bourge, I., Canon, C., Delille, B., Libert, E., and Théate, J.-M.: Carbon dioxide emission from European estuaries, Science, 282, 434-436, 1998.

Fransson, A., Chierici, M., Anderson, L. G., Bussmann, I., Kattner, G., Jones, E. P., and Swift, J. H.: The importance of shelf processes for the modification of chemical constituents in the waters of the Eurasian Arctic Ocean: implication for carbon fluxes, Cont. Shelf Res., 21, 225-242, 2001.

Fransson, A., Chierici, M., and Nojiri, Y.: Increased net $\mathrm{CO}_{2}$ outgassing in the upwelling region of the southern Bering Sea in a period of variable marine climate between 1995 and 2001, J. Geophys. Res., 111, C08008, doi:10.1029/2004JC002759, 2006.

Gattuso, J.-P., Frankignoulle, M., and Wollast, R.: Carbon and carbonate metabolism in coastal aquatic ecosystems, Annual Review of Ecological Systems, 29, 405-434, 1998.

Gerlach, S. A.: Oxygen conditions improve when the salinity in the Baltic Sea decreases, Mar. Pollut. Bull., 28, 413-416, 1994.

Goyet, C., Millero, F. J., O’Sullivan, D. W., Eischeid, G., McCue, S. J., and Bellerby, R. G. J.: Temporal variations of $p \mathrm{CO}_{2}$ in surface sea water of the Arabian Sea in 1995, Deep-Sea Res. Pt. I, 45, 609-623, 1998.

Graham, L. P.: Climate change effects on river flow to the Baltic Sea, Ambio, 33, 235-241, 2004.

Graham, L. P., Hagemann, S., Jaun, S., and Beniston, M.: On interpreting hydrological change from regional climate models, Climatic Change, 81, 97-122, 2007.

Graham, L. P., Chen, D., Christensen, O. B., Kjellström, E., Krysanova, V., Meier, H. E. M., Radziejewski, M., Räisänen, J., Rockel, B., and Ruosteenoja, K.: Projections of Future Anthropogenic Climate Change, in: Assessment of Climate Change for the Baltic Sea Basin, edited by: The BACC Author Team, Springer-Verlag, Berlin, 133-219, 2008. 
Granskog, M. A., Kaartokallio, H., Thomas, D. N., and Kuosa, H.: Influence of freshwater inflow on the inorganic nutrient and dissolved organic matter within coastal sea ice and underlying waters in the Gulf of Finland (Baltic Sea), Estuar. Coast. Shelf S., 65, 109-122, 2005.

HELCOM: Seminar on review of progress made in water protection measures, Baltic Sea Environment Proceedings, 14, 436 pp., 1983.

HELCOM: The Fourth Baltic Sea Pollution Load Compilation (PLC-4), Baltic Sea Environment Proceedings, 93, 189 pp., 2004.

HELCOM: Eutrophication in the Baltic Sea, Baltic Sea Environment Proceedings, 115B, 150 pp., 2009.

Ibanez, J. G., Hernandez-Esparza, M., Doria-Serrano, C., FregosoInfante, A., and Singh, M. M.: Environmental Chemistry, Springer Science + Business Media, LLC, New York, 325 pp., 2007.

Joshi, S. R. and Shukla, B. S.: At initial derivation of formulation Pb-210 dating of sediments, J. Radioanal. Nucl. Ch., 148, 73-79, 1991.

Jurado, E., Dachs, J., Duarte, C. M., and Simó, R.: Atmospheric deposition of organic and black carbon to the global oceans, Atmos. Environ., 42, 7931-7939, 2008.

Kaltin, S. and Anderson, L. G.: Uptake of atmospheric carbon dioxide in Arctic shelf seas: evaluation of the relative importance of processes that influence $p \mathrm{CO}_{2}$ in water transported over the Bering-Chukchi Sea shelf, Mar. Chem., 94, 67-79, 2005.

Kowalczuk, P., Zabłocka, M., Sagan, S., and Kuliński, K.: Fluorescence measured in situ as a proxy of CDOM absorption and DOC concentration in the Baltic Sea, Oceanologia, 52, 431-471, 2010.

Kuliński, K.: Carbon cycle in the Baltic Sea, Ph.D. thesis, Institute of Oceanology PAS, Sopot, 134 pp., 2010.

Kuliński, K. and Pempkowiak, J.: Dissolved organic carbon in the southern Baltic Sea: Quantification of factors affecting its distribution, Estuar. Coast. Shelf S., 78, 38-44, 2008.

Kuliński, K. and Pempkowiak, J.: Accumulation, mineralization and burial rates of organic carbon in the Baltic Sea sediments, Mar. Chem., submitted, 2011.

Kuliński, K., She, J., and Pempkowiak, J.: Short and medium term dynamics of the carbon exchange between the Baltic Sea and the North Sea, Cont. Shelf Res., 31, 1611-1619, 2011.

Kuśmierczyk-Michulec, J., Schulz, M., Ruellan, S., Krüger, O., Plate, E., Marks, R., de Leeuw, G., and Cachier, H.: Aerosol composition and related optical properties in the marine boundary layer over the Baltic Sea, J. Aerosol Sci., 32, 933-955, 2001.

Kuss, J., Roeder, W., Wlost, K. P., and DeGrandpre, M. D.: Timeseries of surface water $\mathrm{CO}_{2}$ and oxygen measurements on a platform in the central Arkona Sea (Baltic Sea): seasonality of uptake and release, Mar. Chem., 101, 220-232, 2006.

Kuusisto, E., Vuglinsky, V., Heino, R., and Kitaev, L.: Hydrology and Land Surfaces, in: Assessment of Climate Change for the Baltic Sea Basin, edited by: The BACC Author Team, SpringerVerlag, Berlin, 392-398, 2008.

Laruelle, G. G., Dürr, H. H., Slomp, C. P., and Borges, A. $\mathrm{V}$ : Evaluation of sinks and sources of $\mathrm{CO}_{2}$ in the global coastal ocean using a spatially-explicit typology of estuaries and continental shelves, Geophys. Res. Lett., 37, L15607, doi:10.1029/2010GL043691, 2010.
Lass, H.-U. and Matthäus, W.: General Oceanography of the Baltic Sea, in: State and Evolution of the Baltic Sea, edited by: Feistel, R., Nausch, G., and Wasmund, N., 1952-2005, Wiley \& Sons, Inc., Hoboken, New Jersey, 5-43, 2008.

Liu, K.-K., Atkinson, L., Quiñones, R. A., and Talaue-McManus, L.: Biogeochemistry of Continental Margins in a Global Context, in: Carbon and Nutrient Fluxes in Continental Margins, edited by: Liu, K.-K., Atkinson, L., Quiñones, R. A., and TalaueMcManus, L., Springer-Verlag, Berlin, 3-24, 2010a.

Liu, K.-K., Tseng, C.-M., Wu, C.-R., and Lin, I.-I.: The South China Sea, in: Carbon and Nutrient Fluxes in Continental Margins, edited by: Liu, K.-K., Atkinson, L., Quiñones, R. A., and Talaue-McManus, L., Springer-Verlag, Berlin, 464-482, $2010 \mathrm{~b}$.

Meier, H. E. M.: Baltic Sea climate in the late twenty-first century: A dynamical downscaling approach using two global models and two emissions scenarios, Clim. Dynam., 27, 39-68, 2006.

Ohlson, M.: Some aspects of a budget for total carbonate in the Baltic Sea, Proceedings of the 17th Conference of the Baltic Oceanographers, Norrköping, 78-83, 1990.

Omstedt, A., Elken, J., Lehmann, A., and Piechura, J.: Knowledge of the Baltic Sea physics gained during the BALTEX and related programmes, Prog. Oceanogr., 63, 1-28, 2004.

Omstedt, A., Gustafsson, E., and Wesslander, K.: Modelling the uptake and release of carbon dioxide in the Baltic Sea surface water, Cont. Shelf Res., 29, 870-885, 2009.

Pätsch, J. and Kühn, W.: Nitrogen and carbon cycling in the North Sea and exchange with the North Atlantic - A model study. Part I. Nitrogen budget and fluxes, Cont. Shelf Res., 28, 767-787, 2008.

Pempkowiak, J.: Enrichment factors of heavy metals in the Southern Baltic surface sediments dated with ${ }^{210} \mathrm{~Pb}$ and ${ }^{137} \mathrm{Cs}$, Environ. Int., 17, 421-428, 1991.

Pempkowiak, J. and Kupryszewski, G.: The input of organic matter to the Baltic from the Vistula River, Oceanologia, 12, 80-98, 1980.

Prowe, A. E. F., Thomas, H., Pätsch, J., Kühn, W., Bozec, Y., Schiettecatte, L.-S., Borges, A. V., and de Baar, H. J. W.: Mechanisms controlling the air-sea $\mathrm{CO}_{2}$ flux in the North Sea, Cont. Shelf Res., 29, 1801-1808, 2009.

Schneider, B., Nausch, G., Nagel, K., and Wasmund, N.: The surface water $\mathrm{CO}_{2}$ budget for the Baltic Proper: a new way to determine nitrogen fixation, J. Marine Syst., 42, 53-64, 2003.

Smith, B., Aasa, A., Ahas, R., Blenckner, T., Callaghan, T. V., de Chazal, J., Humborg, C., Jönsson, A. M., Kellomäki, S., Kull, A., Lehikoinen, E., Mander, Ü., Nõges, P., Nõges, T., Rounsevell, M., Sofiev, M., Tryjanowski, P., and Wolf, A.: Climate-related Change in Terrestrial and Freshwater Ecosystems, in: Assessment of Climate Change for the Baltic Sea Basin, in: The BACC Author Team, Springer-Verlag, Berlin, 221-308, 2008.

Takahashi, T., Sutherland, S. C., Wanninkhof, R., Sweeney, C., Feely, R. A., Chipman, D. W., Hales, B., Friederich, G., Chavez, F., Sabine, C., Watson, A., Bakker, D. C. E., Schuster, U., Metzl, N., Yoshikawa-Inoue, H., Ishii, M., Midorikawa, T., Nojiri, Y., Körtzinger, A., Steinhoff, T., Hoppema, M., Olafsson, J., Arnarson, T. S., Tilbrook, B., Johannessen, T., Olsen, A., Bellerby, R., Wong, C. S., Delille, B., Bates, N. R., and de Baar, H. J. W.: Climatological mean and decadal change in surface ocean $p \mathrm{CO}_{2}$, and net sea-air $\mathrm{CO}_{2}$ flux over the global oceans, Deep-Sea Res. Pt. II, 56, 554-577, 2009. 
Thomas, H. and Schneider, B.: The seasonal cycle of carbon dioxide in Baltic Sea surface waters, J. Marine Syst., 22, 53-67, 1999.

Thomas, H., Pempkowiak, J., Wulff, F., and Nagel, K.: Autotrophy, nitrogen accumulation and nitrogen limitation in the Baltic Sea: A paradox or a buffer for eutrophication?, Geophys. Res. Lett., 30, GL017937, doi:10.1029/2003GL017937, 2003.

Thomas, H., Bozec, Y., Elkalay, K., and de Baar, H. J. W.: Enhanced Open Ocean Storage of $\mathrm{CO}_{2}$ from Shelf Sea Pumping, Science, 304, 1005-1007, 2004.

Thomas, H., Bozec, Y., de Baar, H. J. W., Elkalay, K., Frankignoulle, M., Schiettecatte, L.-S., Kattner, G., and Borges, A. V.: The carbon budget of the North Sea, Biogeosciences, 2, 87-96, doi:10.5194/bg-2-87-2005, 2005.

Thomas, H., Schiettecatte, L.-S., Suykens, K., Koné, Y. J. M., Shadwick, E. H., Prowe, A. E. F., Bozec, Y., de Baar, H. J. W., and Borges, A. V.: Enhanced ocean carbon storage from anaerobic alkalinity generation in coastal sediments, Biogeosciences, 6, 267274, doi:10.5194/bg-6-267-2009, 2009.

Thomas, H., Pempkowiak, J., Wulff, F., and Nagel, K.: The Baltic Sea, in: Carbon and Nutrient Fluxes in Continental Margins, edited by: Liu, K.-K., Atkinson, L., Quiñones, R. A., and TalaueMcManus, L., Springer-Verlag, Berlin, 334-346, 2010.

Tsunogai, S., Watanabe, S., and Satao, T.: Is there a "continental shelf pump" for the absorption of atmospheric $\mathrm{CO}_{2}$ ?, Tellus $\mathrm{B}$, 5, 701-712, 1999.

Voipio, A.: The Baltic Sea, Elsevier Scientific Publishing Company, Amsterdam, 418 pp., 1981.
Wakita, M., Watanabe, Y. W., Watanabe, S., Noriki, S., ans Wakatsuchi, M.: Oceanic uptake rate of anthropogenic $\mathrm{CO}_{2}$ in a subpolar marginal sea: the Sea of Okhotsk, Geophys. Res. Lett., 30, 2252, doi:10.1029/2003GL018057, 2003.

Walsh, J. J.: Importance of continental margins in the marine biogeochemical cycling of carbon and nitrogen, Nature, 350, 53-55, 1991.

Walsh, J. J. and Dieterle, D. A.: $\mathrm{CO}_{2}$ cycling in the coastal ocean. I-A numerical analysis of the southeastern Bering Sea with applications to the Chukchi Sea and the northern Gulf of Mexico, Prog. Oceanogr., 34, 335-392, 1994.

Wasmund, N. and Siegel, H.: Phytoplankton, in: State and Evolution of the Baltic Sea, 1952-2005, edited by: Feistel, R., Nausch, G., and Wasmund, N., Wiley \& Sons, Inc., Hoboken, New Jersey, 441-481, 2008.

Wasmund, N. and Uhlig, S.: Phytoplankton trends in the Baltic Sea, J. Marine Syst., 60, 177-186, 2003.

Wesslander, K., Omstedt, A., and Schneider, B.: Inter-annual and seasonal variations in the air-sea $\mathrm{CO}_{2}$ balance in the central Baltic Sea and the Kattegat, Cont. Shelf Res., 30, 1511-1521, 2010.

Zhai, W., Dai, M., Cai, W.-J., Wang, Y., and Wang, Z.: High partial pressure of $\mathrm{CO}_{2}$ and its maintaining mechanism in a subtropical estuary: the Pearl River estuary, China, Mar. Chem., 93, 21-32, 2005. 